\title{
NEW SPECIES OF ARGE SCHRANK, 1802 (HYMENOPTERA, ARGIDAE) FROM TURKEY
}

\author{
Emin Kaplan ${ }^{1}$ and Attila Haris ${ }^{2}$ \\ ${ }^{1}$ Bingöl University, Faculty of Agriculture, Department of Plant Protection, Bingöl, Turkey \\ E-mail:eminkaplan021@gmail.com, https://orcid.org/0000-0002-9194-7018 \\ ${ }^{2}$ Ripl-Rónai Municipal Museum, Kaposvár, Hungary \\ E-mail: attilaharis@yahoo.com,https://orcid.org/0000-0001-5007-1307
}

Arge yildirimi Haris et Kaplan sp. n. is described from Turkey, Diyarbakir Province and compared to Arge pectoralis (Leach, 1817) and Arge frivaldszkyi (Tischbein, 1852).

Key words: Hymenoptera, Argidae, Arge yildirimi sp. n., Diyarbakır, Turkey.

\section{INTRODUCTION}

This paper is part of a project Insects of Anatolia with a special focus on the fauna of Bingöl and Diyarbakir provinces, conducted by the Plant Protection Department of Bingöl University, Turkey.

In 2018 and 2019, the senior author captured 6 females in the genus Arge Schrank, 1802 in different locations of Diyarbakir Province. Although the new species runs to Arge frivaldszkyi (Tischbein, 1852) in the Palaearctic key (GusSAKOVSKIJ 1935), it also shows a close relationship with one Nearctic species.

The first argid sawflies from Turkey, including Arge Schrank, 1802, were recorded by Benson (1968) and Wolf (1968). So far, only one taxon of Arge, namely Arge fuscipes seljuki Benson, 1968 has been described from Turkey. Currently, 25 Arge species are recorded from the country (ÇALMaşUR \& ÖzBEK 2006).

\section{MATERIAL AND METHODS}

The material was collected by sweeping grass and a variety of flowering plants in meadows and pastures. Sampling was performed throughout the vegetation season, namely 2 days in March, 13 days in April, 21 days in May, 7 days in June, 2 days in July, 3 days in August and 3 days in September in 2018 and 11 days in March, 16 days in April, 13 days in May, 6 days in June, 5 days in July, 4 days in August and 3 days in September in 2019.

For the identification and differential diagnosis of Arge yildirimi Haris et Kaplan sp. n. the following papers and monographs were studied: SMith (1989), Benson (1968), GusSAKovskij (1935), VAsilenko (2010), Örgen and BasibÜYÜK (2006), SAINi (2009), Choi et al. (2016), Hara et al. (2012, 2007), Hara and Shinohara (2008, 2011), Malagon-Aldana et al. (2021), Muche (1977), Okutani, (1956), Shinohara and Hara (2008, 2009), Shinohara et al. (2009, 2011, 2015), TAKeuchi (1932), Wei $(2004,2005)$, Wei and Nie $(1998,1999)$, WeI and Niu (2010), Wei and Wen (1997, 1999 and 2002), Wen and Wei (1998), Zhelochovtsev (1988) and ZомвоRI (1978). 


\section{Arge yildirimi Haris et Kaplan sp. n.}

(Figs 1-5)

Arge frivaldszkyi: Kaplan et al. 2018 (misidentification).

Type material. Holotype: Lice: Yalaza, N 38²0'16.33", E 40 40’35.45", 921 m, 25. 04. 2018, 1 female, leg. Emin Kaplan. Deposited in the Rippl-Rónai Museum, Kaposvár, Hungary.

Paratypes: Eğil: Yatır, N $38^{\circ} 08^{\prime} 09.41^{\prime \prime}$, E 40 08' 56.18", 836 m, 28. 03. 2019, 1 female; Kocaköy, Ambar, N $38^{\circ} 16^{\prime}$ 07.99", E 40²8' 29.61", 733 m, 24. 04. 2018, 1 female; Lice, Beni, N $38^{\circ} 20^{\prime}$ 07.29", E $40^{\circ} 38^{\prime} 57.00^{\prime \prime}, 1124$ m, 25. 04.2018, 1 female; Kutlu, N $38^{\circ} 21^{\prime}$ 37.62", E $40^{\circ}$ 46’ 28.39", 825 m, 28. 04. 2018, 1 female; Oyuklu, N 38 19’ 44.71", E 40 45’ 31.90", 939 m, 28. 04. 2018, 1 female; all leg. Emin Kaplan (3 in Rippl-Rónai Museum; 2 in Bingöl University).

Female: Head, including antennae and mouthparts, bluish black. Thorax predominantly orange, bluish black are: legs, tegulae, prosternum, mesosternum, metasternum, katepimeron, metapleuron, mesoscutellum, metascutellum, and metanotum. Abdomen predominantly orange, bluish black are: first tergite, narrow anterior margin of second tergite, last abdominal segment and ovipositor. Wings weakly infumate, subcostal area strongly infumate; veins, including costa, subcosta and stigma black. Head behind the eyes moderately expanded. Gena about as long as diameter of anterior ocellus, clypeus triangularly excised, clypeal excision about $0.4 \times$ as deep as clypeal median length. Frontal basin triangularly elongated down to level of antennal sockets and clearly carinated. Labrum with straight anterior margin. Labrum, clypeus, inner orbits and frontal area shallowly and densely punctured, shiny. Temples and vertex smooth and shiny. OOL : POL : OCL: 9:11:11. Temples, vertex not carinated posteriorly. Gena with short sharp carina. Mesonotum, mestascutellum and mesopleuron smooth and shiny. Mesoscutellum with minute, moderately dense punctures, shiny. Basalis and cubitalis of anterior wing meet in one point on subcosta. Abdominal tergites with fine coriaceous surface sculpture, shiny. Hind tibial calcars subequal and about as long as width of hind tibia. Hind tibial spur : apical width of hind tibia: $10: 9$. Hind tibia with an additional submedian spine. Claws simple. Head and thorax covered with short, sparse, white pubescence. Lancet slender with 18 serrulae (Fig. 5). Length: $7.6 \mathrm{~mm}$.

Variation: one paratype has 2 small and rounded orange spots on sides of mesoscutellum. Length: 7.6- $8.6 \mathrm{~mm}$.

Male: Unknown.

Etymology: The new species is dedicated to Professor Dr. Erol Yildirim (Ataturk University, Faculty of Agriculture, Department of Plant Protection, Erzurum, Turkey).

\section{DISCUSSION}

Differences: In the classification of Sмiтн (1989), the new species is a member of the clavicornis group having sharply prominent supraclypeal crest broken rectangularly on the lower third; lancet is slender, without a larger gap between 2nd and 3rd serrulae. It is not similar to any member of the clavicornis group, but superficially looks like Arge pectoralis (Leach, 1817). 
These two species differ in body size $(7.6-8.6 \mathrm{~mm}$ in A. yilidirimi versus $9.0-11.5 \mathrm{~mm}$ in $A$. pectoralis). In the form of the frontal crest, it is strongly elevated in the new species, versus the hardly elevated frontal crest in A. pectoralis. The colour of mesoscutellum is also different: the mesoscutellum is orange in Arge pectoralis, but it is always black in A. yildirimi.
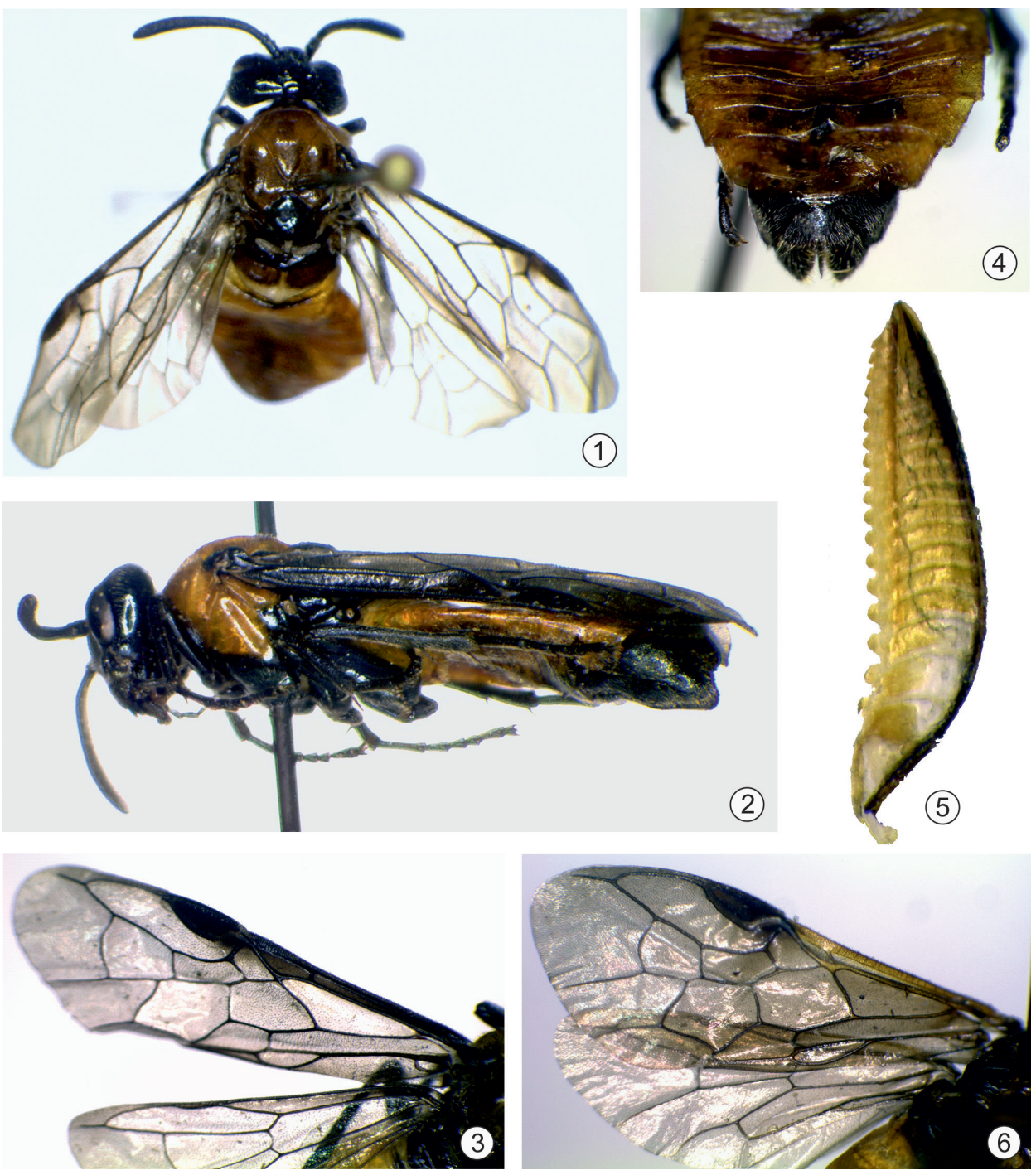

Figs 1-6. 1-5 = Arge yildirimi Haris et Kaplan sp. n.: 1-2 = holotype: $1=$ dorsal view, 2 = lateral view; $3=$ anterior wing, $4=$ apex of abdomen, $5=$ lancet. $6=$ Anterior wing of Arge frivaldszkyi (Tischbein, 1852). (Photos: A. Haris) 
Finally, the lancet is completely different in these 2 species: please, compare Fig. 5 with Fig. 50 in Sмiтн (1989). In the Palaearctic (GussakovsкiJ, 1935; Muche, 1977), A. yildirimi is most similar to Arge frivaldszkyi (Tischbein, 1852). These two species differ as follows: the frontal basin of the $A$. yildirimi is triangularly elongated down to the level of the antennal sockets and clearly carinate; in A. frivaldszkyi this elongate and carinate frontal basin is missing. In the fore wing of $A$. yildirimi, veins basalis and cubitalis meet at one point on the subcosta, and the wings are weakly infumated, with subcostal area strongly and strikingly infumate, veins, including costa, subcosta and stigma black (Fig. 3). In contrast, the wings of $A$. frivaldszkyi are uniformly infumated, and the subcostal area is not darker than the other parts of the wing, costa and subcosta yellow and basalis and cubitalis of anterior wing reach the subcosta having distance equal with subcostal cross-vein (Fig. 6). The last abdominal segment in A. yildirimi is bluish black (Fig. 4), while in A. frivaldszkyi it is orange, only the ovipositor is black. Finally, all dark colour in $A$. yildirimi is black with strong blue lustre, while in $A$. frivaldszkyi it is black without any metallic lustre. We also examined the description of Arge schmiedeknechti (Costa, 1890), which is considered the only one junior synonym of $A$. frivaldszkyi. Based on the original description (CosTA, 1890): „Rufo-testacea, antennis, capite, scutello, metanoto, pectoris disco pedibusque nigris alis aeque saturate fuliginosis, stigmate venisque fusco-nigris vena costali tantum flava - Long mill 7", we conclude that the synonym status is correct and it is not conspecific with the new species.

The biotope of the new species: all specimens were captured by sweep netting alongside the edges of oak forests dominated by Quercus brantii and Q. infectoria. Oak forests were mixed with the following trees and shrubs: Celtis tournefortii, Cerasus mahaleb, Fraxinus angustifolia, Juniperus oxycedrus, Paliurus spia-christi and Pistacia terebintus. The typical herbaceous plants of this biotope are: Acantholimon acerosum, Achillea vermicularis, Astragalus gummifer, Alcea apterocarpa, A. calverti, Anthemis cotula, Anthemis wiedemanniana, Bromus tomentellus, Cardus nutans, Cotoneaster nummularia, Crataaegus orientalis, Eryngium billardieri, Euphorbia cheiradenia, Ficus cariaca ssp. rupestris, Genista albida, Gundelia tournefortii, Gypsophila ruscifolia, Hypericum scabrum, H. perforatum, Onosma trachytrichum, Nigella arvensis, Phlomis armeniaca, Pisum sativum, Poa bulbosa, Prunus divaricata, Scutellaria orientalis, Sinapis arvensis, Thymus kotschyanus, Trifolium resupinatum, Verbascum sp., Vicia sativa and V. noeana.

Distribution of the new species: specimens were captured in the montane region of Anatolia between 733 and 1124 meters above sea level. 
Acknowledgements - We express thanks to Dr. Levente Ábrahám (director of RipplRónai Museum) and Dr. Yakup Yapar (professor of botany at Bingöl University). Also, to the reviewers of this paper for their corrections and advice making our paper better.

\section{REFERENCES}

Benson, R. B. (1968): Hymenoptera from Turkey, Symphyta. - Bulletin of the British Museum (Natural History), Entomology series 22(4): 111-207.

https://doi.org/10.5962/bhl.part.9952

Çalmaşur, Ö \& Özbek, H. (2006): Check-list of the Argidae fauna (Hymenoptera: Symphyta) of Turkey. - Zoology of the Middle East 39: 89-96.

https://doi.org/10.1080/09397140.2006.10638187

Choi, J. K., Lee, S. B., Wei, M. \& Lee, J. W. (2016): Three new species of the genus Arge (Hymenoptera: Symphyta: Argidae) from South Korea with key to species of the subfamily Arginae. - Journal of Asia-Pacific Entomology 9: 183-193. https://doi.org/10.1016/j.japb.2016.02.001

Costa, A. (1890): Miscellanea entomologica. - Atti della Reale Accademia delle scienze fisiche e matematiche di Napoli 5: 1-19.

GussakovsкiJ, V. V. (1935): Insectes Hyménoptères, Chalastogastra 1. - Fauna SSSR, Moskva, Leningrad 2(1): 1-453.

Hara, H., Kojima, H. \& Shinohara, A. (2007): Arge solowi-yofka (Hymenoptera, Argidae) feeding on Betula ermanii, newly recorded from Japan. - Japanese Journal of Systematic Entomology 13: 85-89. https://www.cabdirect.org/cabdirect/abstract/20073193525

Hara, H. \& Shinohara, A. (2008): The species-group of Arge aenea (Insecta, Hymenoptera, Argidae). - Bulletin of the National Museum of Nature and Science, Series A 34: 77-94.

Hara, H. \& Shinohara, A. (2011): Arge enkianthus n. sp. (Hymenoptera, Argidae) feeding on Enkianthus campanulatus in Japan. - Bulletin of the National Museum of Nature and Science, Series A 38: 21-32.

Hara, H., Shinohara, A. \& Ibuki, S. I. (2012): Arge obesa n. sp. (Hymenoptera, Argidae) Feeding on Carpinus and Ostrya in Japan, with taxonomic notes on Hylotoma japonica. - Bulletin of the National Science Museum, Series A, Zoology, Tokyo 38(3): 125-143.

Kaplan, E., Mart, A., Haris, A. \& Yildirim, E. (2018): Contribution to the knowledge of the Megalodontesidae, Argidae, Cimbicidae, Cephidae and Tenthredinidae (Symphyta: Hymenoptera) fauna from Bingöl and Diyarbakır provinces of Turkey. - Natura Somogyiensis 32: 109-120. https://doi.org/10.24394/NatSom.2018.32.109

Malagon-Aldana, L. A., Shinohara, A., Smith, D. R. \& Vilhelmsen, L. (2021): Comparative anatomy of the larvae of argid sawflies (Hymenoptera: Argidae): a phylogenetic approach. - Organisms Diversity \& Evolution 21(1): 1-32. https://doi.org/10.1007/s13127-021-00485-0

Muche, W. H. (1977): Die Argidae von Europa, Vorderasien und Nordafrika (mit Ausnahme der Gattung Aprosthema) (Hymenoptera, Symphyta). - Entomologische Abhandlungen. Staatliches Museum für Tierkunde in Dresden, Leipzig 41, (Supplement): 23-59. 
Окитаni, T. (1956): New sawflies from Japan. (Studies on Symphyta VI). - Insecta Matsumurana, Sapporo 20(3-4): 97-99.

Örgen, S. H. \& Basıbüyüк, H. H. (2006): Members of the sawfly family Argidae (Hymenoptera) from Turkey. Pp. 393-399. - In: Blank, S. M., Schmidt, S., TAEger, A. (eds): Recent sawfly research: synthesis and prospects. - Goecko \& Evers, Keltern. 701 pp. https://doi.org/10.1080/09397140.2006.10638187

SaIni, M. S. (2009): Families Argidae, Cimbicidae, Diprionidae, Pamphiliidae, Siricidae, Xiphydriidae, Orussidae. - In: SAINI, M. S. (ed.): Indian sawflies biodiversity. Keys, catalogue E illustrations. Bishen Singh Mahendra Pal Singh, Dehra Dun 6: 1-168.

Shinohara, A. \& Hara, H. (2008): Taxonomy, distribution and life history of Abelia -feeding sawfly, Arge suzukii (Hymenoptera, Argidae). - Japanese Journal of Systematic Entomology 14: 29-47.

Shinohara, A. \& Hara, H. (2009): Arge indicura n. sp. feeding on Potentilla and Sanguisorba (Insecta, Hymenoptera, Argidae) from Japan. - Bulletin of the National Museum of Nature and Science, Series A (Zoology), Tokyo 35(1): 55-71.

Shinohara, A., Hara, H. \& Kim J. W. (2009): The species- group of Arge captiva (Insecta, Hymenoptera, Argidae). - Bulletin of the National Museum of Nature and Science, Series A 35: 249-278.

Shinohara, A., Hara, H., Lee, H. S. \& Lyu, D. (2011): Taxonomy, distribution, and life history of the Rubus-feeding sawfly Arge hasegawae (Hymenoptera: Argidae). - Proceedings of the Entomological Society of Washington 113(4): 508-518. https://doi.org/10.4289/0013-8797.113.4.508

Shinohara, A., Wei, M. C. \& Kiyoshi, T. (2015): Arge pyracanthae n. sp. (Hymenoptera: Argidae) feeding on Pyracantha fortuneana in Hunan Province, China. - Zootaxa 3947(3): 407-416. https://doi.org/10.11646/zootaxa.3947.3.7

Sмiтн, D. R. (1989): The sawfly genus Arge (Hymenoptera: Argidae) in the Western Hemisphere. - Transactions of the American Entomological Society, Philadelphia 115: 83-205.

TAKeuChi, K. (1932): A revision of the Japanese Argidae. - Transactions of the Kansai Entomological Society 3: 27-42.

Vasilenko, S. V. (2010): A new species of the genus Arge Schrank, 1802 (Hymenoptera, Argidae) from West Siberia. - Eurasian Entomological Journal 9(4): 681-682.

WEI, M. (2004): Hymenoptera: Argidae. Pp. 109-111. - In: YANG, X. (ed.): Insects of the Great Yarlung Zangbo Canyon of Xizang, China. - China Agricultural Science and Technology Press, Beijing, 339 pp.

WeI, M. (2005): Argidae. Pp. 446-455. - In: Jin, D., LI, Z. (eds): Insects from Xishui Landscape. - Guizhou Science and Technology Publishing House, Guiyang, 616 pp. [in Chinese, abstract in English]

WeI, M. \& Nie, H. (1998): Hymenoptera: Pamphiliidae, Cimbicidae, Argidae, Diprionidae, Tenthredinidae, Cephidae. Pp. 344-391. - In: Wu, H. (ed.): Insects of Longwangshan Nature Reserve. - China Forestry Publishing House, Beijing, 404 pp. [in Chinese, abstract in English]

Wei, M. \& Nie, H. (1999): Sawflies collected from Mt. Dabieshan, Henan (Hymenoptera: Tenthredinomorpha. Pp. 167-185. - In: Shen, X. \& PeI, H. (eds): Insects of the mountains Funiu and Dabie regions. (The fauna and taxonomy of insects in Henan, Vol. 4). - China Agricultural Science and Technology Press, Beijing, 415 pp.

Wei, M. \& Niu, G. (2010): Hymenoptera: Argidae, Cimbicidae, Tenthredinidae. - Pp. 337362. In: $\mathrm{XU}_{\mathrm{U}}, \mathrm{H}$. \& $\mathrm{Y}_{\mathrm{E}}, \mathrm{X}$. (eds): Insects of Fengyangshan National Nature Reserve. - China Forestry Press, Beijing. 397 pp. [in Chinese, abstract in English] 
WeI, M. \& Wen, J. (1997): Six new species of Arge Schrank (Hymenoptera: Argidae) from China. - Entomotaxonomia, Wugong 19(Suppl.): 25-34.

WeI, M. \& Wen, J. (1999): Six new species of Argidae from south slope of Mt. Funiu (Hymenoptera: Tenthredinomorpha). Pp. 128-135. - In: SHEN, X. \& PEI, H. (eds): Insects of the mountains Funiu and Dabie regions. (The fauna and taxonomy of insects in Henan, Vol. 4). - China Agricultural Science and Technology Press, Beijing, 415 pp. [in Chinese, abstract in English]

Wei, M. \& Wen, J. (2002): Argidae. Pp. 422-427. - In: Li, Z. \& Jin, D. (eds): Insects from Maolan Landscape. - Guizhou Science and Technology Publishing House, Guiyang, 615 pp. [in Chinese, abstract in English]

Wen, J. \& WeI, M. (1998): New species of Argidae from Funiushan (Hymenoptera: Tenthredinomorpha). Pp. 100-111. - In: SHEN, X. \& PEI, H. (eds): Insects of the mountains Funiu and Dabie regions. The fauna and taxonomy of insects in Henan. - China Agricultural Science and Technology Press 4: 415 pp.

Wolf, F. (1968): Hymenopteres Symphytes de Turquie. - Bulletin des Recherches agronomiques de Gembloux 3(3): 562-565.

Zhelochovtsev, A. N. (1988): Otryad Hymenoptera - Pereponchatokrylye, podotryad Symphyta - Sidyachebryukhie. Pp. 7-234. In: Medvedev, K. H. (ed.): Opredelitel nasekomykh evropeiskoi chasti SSSR (Keys to the insects of the European part of the USSR), Vol. 3 Hymenoptera, Part 6. - Nauka, Leningrad. https://doi.org/10.5962/bhl.title.46334

Zombori, L. (1978): Two new sawfly species from Armenia (Hymenoptera: Symphyta). Acta Zoologica Academiae Scientiarum Hungaricae 24(3-4): 451-454.

Received March 28, 2021, accepted July 22, 2021, published November 19, 2021 
